\title{
THE PRINCIPLES OF MODERN ARCHITECTURAL DESIGN AS OBSERVED IN PARAHYANGAN CATHOLIC UNIVERSITY'S POST- GRADUATE STUDIES BUILDING
}

\author{
${ }^{1}$ Bryan Nurman Zachrie. ${ }^{2}$ Caecilia Wijayaputri ST., MT. \\ ${ }^{1}$ Student in the Bachelor's (S-1) Study Program in Architecture \\ at Parahyangan Catholic University \\ ${ }^{2}$ Senior lecturer in the Bachelor's (S-1) Study Program in Architecture \\ at Parahyangan Catholic University
}

\begin{abstract}
The post-Independence era saw the beginning of the development of modern architecture in Indonesia. In this particular era the profession of architect emerged as a requirement that eventually also turned into one of the fields that played a role in the development of Indonesian architecture. As one of the first architects, Mohammad Soesilo joined in participating in drawing up the main principles of architectural design valid for that era, a theorem that can be said to be influential to this day, serving as a set of general guidelines. The lack of data available on the dawn of architectural development has created a certain vagueness concerning these principles. In the post-Independence era, Indonesian architects were still strongly influenced by the principles of design being developed, that is to say those governing modern architecture.

The purpose of this research is to deepen our insight into into the various principles of architectural design in the post-Independence era to establish how big the influence has been of the principles governing modern architecture that became the guidelines for designs made by Indonesian architects in those days, in order to be able to determine their impact on the design of architectural works in Indonesia itself.

This research has been conducted by examining one of the buildings designed by Mohammad Soesilo, namely Parahyangan Catholic University's Post-graduate Studies Building. The focus of research revolves around the question whether this building can be classified as one designed with the principles of modern architecture in mind because the design of its physical shape was influenced by the seven variables using the terminology of modern architecture. These seven variables have influenced the attainment of function, expression, and technology in Parahyangan Catholic University's Post-graduate Studies Building as one that has been well designed.
\end{abstract}

\section{PRINSIP PERANCANGAN ARSITEKTUR MODERN PADA GEDUNG PASCA-SARJANA UNIVERSITAS KATOLIK PARAHYANGAN}

\author{
${ }^{1}$ Bryan Nurman Zachrie. ${ }^{2}$ Caecilia Wijayaputri ST., MT. \\ ${ }^{1}$ Mahasiswa S1 Program Studi Arsitektur Universitas Katolik Parahyangan. \\ ${ }^{2}$ Dosen Pembimbing S1 Program Studi Arsitektur Universitas Katolik Parahyangan.
}

\begin{abstract}
Abstrak- Masa pasca kemerdekaan adalah awal mula berkembangnya arsitektur modern di Indonesia. Pada masa ini profesi arsitek muncul sebagai sebuah kebutuhan yang akhirnya juga menjadi salah satu bidang yang berperan dalam perkembangan arsitektur Indonesia.

Sebagai salah satu arsitek pertama Mohhamad Soesilo turut berpartisipasi dalam mencetak prinsip-prinsip perancangan arsitektur yang berlaku pada masa itu dan dapat dikatakan masih berpengaruh juga di zaman ini sebagai sebuah pedoman.

Kurangnya data akan penelitian awal perkembangan arsitektur mengakibatkan pengetahuan tentang prinsipprinsip ini tidak jelas. Di era pasca kemerdekaan, arsitek Indonesia masih banyak dipengaruhi oleh prinsipprinsip rancangan yang yang berkembang yaitu prinsip arsitektur modern.
\end{abstract}

\footnotetext{
${ }^{1}$ Corresponding Author: Bryanzachrie@gmail.com
} 
Penelitian ini ditujukan untuk memperdalam wawasan mengenai prinsip-prinsip rancangan arsitektur di masa pasca kemerdekaan untuk mengetahui seberapa besar pengaruh prinsip arsitektur modern menjadi pedoman perancangan untuk para arsitek Indonesia di masa pasca kemerdekaan sehingga kita dapat mengetahui pengaruh prinsip arsitektur modern terhadap rancangan karya arsitektur di Indonesia sendiri.

Penelitian ini dilakukan dengan mengkaji salah satu objek bangunan karya Mohammad Sosilo yaitu Gedung Pasca-Sarjana Universitas Katolik Parahyangan. Perihal yang menjadi titik fokues penelitian adalah Apakah bangunan tersebut dapat diklasifikasikan sebagai bangunan yang dirancang dengan kaidah arsitektur modern dan bagaimana prinsip perancangan arsitektur modern berpengaruh terhadap karya rancangangan Mohammad Soesilo.

Melalui pennelitian ini ditemukan bahwa Gedung Pasca-Sarjana Universitas Katolik Parahyangan dapat di definisikan sebagai sebuah bangunan yang menggunakan kaidah prinsip perancangan arsitektur modern karena perancangan bentuk fisik bangunan yang dipengaruhi oleh ketujuh variable bahasa arsitektur modern. Ketujuh variable ini berpengaruh terhadap pancapaian fungsi, ekspresi dan teknologi pada Gedung Universitas Katolik Parahyangan sebagai gedung yang baik.

Kata-kata kunci : Prinsip Arsitektur, Prinsip Arsitektur Modern, Arsitektur Pasca merdeka

\section{PENDAHULUAN}

\subsection{LATAR BELAKANG PENELITIAN}

Profesi arsitektur merupakan salah satu bidang yang mulai berkembang di Indonesia pada era pasca kemerdekaan. Setelah merdeka, pembangunan infrastruktur dan tata kota menjadi salah satu tuntutan utama dalam perkembangan negara menuju kemakmuran, sehingga timbul profesi arsitektur untuk menunjang kebutuhan tersebut. Dengan adanya tuntutan pembangunan timbul juga masalah dimana Indonesia sendiri di masa itu masih membutuhkan ahli dalam tata rencana dan tata kelola pembangunan dan bidang arsitektur muncul sebagai salah satu bidang pengetahuan yang diperdalam di Indonesia.

Sebagai salah satu bidang yang masih dalam tahap studi mentah di indonesia, tentunya banyak kurikulum, teori dan pedoman yang diambil dari pembelajaran arsitektur di luar negri, terutama karena para pengajar yang di dominasi oleh para arsitek dari Belanda, pada masa tersebut prinsip arsitektur yang sedang berkembang merupakan prinsip prinsip arsitektur modern. Dengan pernyataan tersebut dapat dikatakan bahwa arsitektur pada zaman pasca kemerdekaan di Indonesia sangat dipengaruhi dan berkembang seiring dengan dipraktikan prinsip-prinsip arsitektur modern.

Pada era pasca kemerdekaan para arsitek di Indonesia belum dapat dikatakan memiliki karakter dan identitas perancangannya sendiri, dikarenakan pengaruh pendidikan arsitektur yang datang dari luar, maka kebanyakan prinsip yang digunakan adalah prinsip perancangan paling dasar yang berlaku yakni prinsip penataan serta langgam arsitektur yang menggambarkan kebanyakan arsitektur modern yang sedang sangat diminati dio masa itu.

Ada beberapa faktor di masa itu yang diakibatkan oleh sistem pendidikan arsitektur serta pendalaman pada prinsip prinsip arsitektur yang berpengaruh terhadap prinsip rancangan arsitek di Indonesia sampai zaman kini. Para arsitek di zaman itu menjadi idola dan panutan bagi banyak arsitek di Indonesia dan berpengaruh terhadap prinsip prinsip yang dipegang oleh para arsitek di zaman ini juga. Menjadi salah satu pertanyaan penting sampai zaman ini bahwa sebenarnya apa yang menjadi benang merah prinsip perancangan arsitek di Indonesia. Salah satu bagian penting yang harus diperdalam adalah bagian cerita dan fakta sejarah yang hilang tentang arsitektur pada awal mulanya arsitektur berkembang di Indonesia.

Untuk menjawab pertanyaan tersebut tentunya sangat sulit karena banyaknya data dan arsip tentang arsitektur Indonesia pada masa itu yang terbengkalai atau bahkan hilang dan tidak bisa dijawab dalam satu penelitian saja. Banyak penelitian terhadap bangunan arsitektur pada masa pasca modern yang perlu diteliti dan dikomparasi prinsip perancangannya untuk mencari prinsip perancangan para arsitek Indonesia pada zama pasca kemerdekaan secara 
umum, bahkan mungkin tidak satu prinsip yang dilakukan, namun langkah pertama yang dapat dilakukan adalah tindakan para peneliti arsitek di zaman ini untuk mengambil peran melengkapi komponen yang menjadi bagian dari penelitian besar itu.

Salah satu arsitek yang kita kenal sebagai arsitek pertama Indonesia adalah Mohammad Soesilo. Sebagai seseorang yang telah terjun dalam dunia pembangunan di Indonesia semenjak era pasca modern, tentunya ia merupakan salah satu arsitek yang dalam perancangannya menerapkan prinsip-prinsip perancangan arsitektur modern yang berkembang pada masa itu. Sebagai bidang yang masih cukup mentah di Indonesia pada masa itu pertanyaan berikutnya adalah berapa besar presentase dari prinsip perancangan arsitektur modern dengan prinsip perancangan yang berlaku pada dasarnya.

Penelitian ini ditujukan untuk melengkapi lembar kosong arsitektur pasca kemerdekaan yang berkembang berdampingan dengan arsitektur modern sehingga para arsitek dapat mengetahui dasar dan prinsip perancangan arsitektur di indonesia yang berlaku dan berpengaruh terhadap perkembangan Arsitektur di Indonesia.

Berawal dari (1) rumusan masalah yaitu melihat fenomena yang telah dijabarkan di atas, maka identifikasi masalah dalam kasus penelitian tersebut merupakan prinsip perancangan arsitektur modern yang diperkirakan mempengaruhi perkembangan arsitektur pada masa pasca-kemerdekaan di Indonesia dan menjadi unsur penting untuk dikaji lebih lanjut. Kemudian (2) pertanyaan penelitian adalah bagaimana prinsip arsitektur modern diterapkan pada gedung Pasca-Sarjana Universitas Katolik Parahyangan. (3) Penelitian ini ditujukan untuk melengkapi lembar kosong arsitektur pasca-kemerdekaan yang berkembang dipengaruhi oleh prinsip perancangan arsitektur modern. (4) Manfaat penelitian ini untuk memberikan informasi sehingga para arsitek dapat mengetahui dasar dan prinsip perancangan arsitektur di masa pasca-kemerdekaan yang berlaku dan berpengaruh terhadap perkembangan arsitektur di Indonesia hingga masa kini. Diharapkan dapat menjadi bahan referensi atau sebuah penelitian dapat dilakukan terhadap arsitek masa pasca kemerdekaan yang lain dan terus dikembangkan dan disempurnakan di kemudian hari oleh para mahasiswa maupun professional. Dengan menggunakan (5) jenis penelitian deduktif-kualitatif. (6) tempat dan waktu penelitian dilakukan di Bandung selama kurang lebih empat bulan. Peneliti mengambil sampel gedung Pasca-Sarjana Universitas Katolik Parahyangan.

\section{KAJIAN TEORI}

\subsection{ARCHITECTURE}

Arsitektur merupakan segala proses maupun hasil, dari perencanaan, perancangan, dan pembangunan sebuah bangunan. Yang meliputi proses perencanaan dan perancangan sebuah bentuk, ruang, dan suasana untuk mencerminkan pertimbangan fungsional, teknis, social, lingkungan, dan estetika. Dengan memainkan bahan, teknologi cahaya dan bayangan, untuk mendapatkan suasana yang diinginkan. Dalam praktek asitektur juga meliputi aspke pragmatis untuk mewujudkan bangunan seperti struktur, penjadwalan, estiasi biaya, estimasi pembangunan.

\subsection{GOOD ARCHITECTURE}

Dalam buku Vitruvius yang berjudul "10 Books on Architecture" disebutkan bahwa Arsitektur memiliki 3 syarat yang umum untuk menjadi arsitektur yang baik, yaitu Firmitas, Utilitas, dan Venustas. Arsitektur yang baik pada tahap awal harus memenuhi syarat Utilitas.

Bangunan yang indah dan kuat namun tidak memenuhi fungsi penggunanya tidak akan disebut sebagai arsitektur yang baik. Hal tersebut jauh dari Arsitektur yang baik 
dikarenakan bangunan tersebut tidak sama sekali mengakomodasi kebutuhan penggunanya. Klien sebagai pemberi tugas juga tidak terpenuhi keinginannya.

Kedua, arsitektur yang baik akan tahan terhadap situasi apapun. Dalam hal ini peran Firmitas sangat dibutuhkan. Hal ini dikarenakan arsitektur yang kuat akan strukturnya, materialnya dalam menghadapi kejamnya iklim serta factor - factor lainnya yang masih menyebabkan bangunan tersebut berdiri sangat dibutuhkan untuk memastikan kenyamanan penggunanya dalam penggunaan bangunan tersebut.

Setelah kedua aspek tersebut terpenuhi, aspek Venustas menjadi hal penentu yang akan dibahas untuk menjadi arsitektur yang baik. Hal ini cukup sulit karena tidak akan sepenuhnya dinilai secara objektif. Hal ini dikarenakan keindahan bukanlah hal yang dengan mudah disepakati secara sepenuhnya oleh semua orang, namun suatu keindahanan juga memiliki standar sehingga hal tersebut disebut sebagai hal yang indah. Vitrivius berpikir bahwa alam sebagai sumber inspirasi keindahan yang paling manjur untuk dipelajari. Salah satu contohnya adalah proporsi badan manusia. proporsi manusia adalah salah satu hal yang indah. Perpaduan antara lekuk tubuh bulat dan geometris persegi. Bentuk tubuh manusia bisa dijadikan pelajaran untuk berarsitektur yang baik, dengan memperhatikan proporsi antara badan, kaki, dan kepala manusia dan juga menjadi badan, kepala, kaki bangunan..

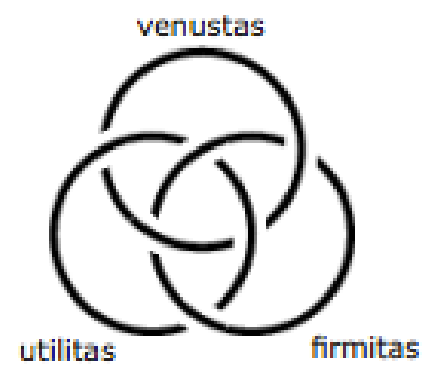

Figur 1. The Vitruvian Virtues of Architecture : Utilitas, Venustas, Firmitas

Tidak seperti makna utiitas pada dewasa ini yang berkelut dibidang teknis belaka. Utilitas menurut Vitruvius adalah bagian yang berkaitan dengan fungsi. Venutas sendiri merupakan aspek yang berkaitan dengan keindahan secra spesifik. Firmitas berdiri sebagai aspek yang berkaitan langsung dengan sifat-sifat structural dan material sebuah bangunan yang dapat menggambarkan kemajuan teknologi pada bangunan.

Perancangan sebuah bangunan tentunya memiliki ketiga prinsip dalam perancangannya untuk dapat dikatakan sebagai sebuah bangunan yang baik yakni; Utilitas, Venustas dan Firmitas. Dalam ketiga prinsip tersebut diharapkan menjadi pertimbangan dalam merancang sebuah bangunan.

Adanya prinsip ini berfungsi menjadi batasan dalam rancangan, karena tanpa adanya batas, bangunan tersebut tidak akan memiliki makna, sehingga berdiri sebagai sebuah pengisi bagi ruang kosong saja. Dapat dikatakan dalam perancangan ketiga prinsip tersebut merupakan dasar dalam perancanaan sebuah bangunan, akhir kata, setiap bangunan pasti miliki ketiga unsur tersebut.

\subsection{MODERN LANGUAGE OF ARCHITECTURE}

Arsitektur modern berpegangan pada pemikiran yang bertentangan dengan arsitektur klasik, dimana arsitek modern lebih kritis dalam merancang dan melihat aspek asepek seperti aspek pengguna dan kegiatan sebagai salah satu pembentuk pada rancangan bangunan yang krusial. Bangunan tidak lagi terbentu berdasarkan gubahan semata saja, tapi dari tiap elemen bangunan memiliki makna lebih dari sekedar gubahan. 
Arsitektur modern berpegangan pada 7 variabel yang menjadi dasar pedoman dalam perancangan, sehingga untuk menciptakan sebuah bangunan yang modern 7 variabel yang bertentangan dengan prinsip perancangan arsitektur klasik sehingga disebut sebagai "invariabel" itu menjadi pedoman dasar perancangan.

Arsitektur modern adalah arsitektur yang dirancang menggunakan prinsip-prinsip yang digunakan sebagai dasar pemikiran para arsitek pada zaman modern. Prinsip-prinsip perancangan pada arsitektur modern dilihat merupakan pemikiran yang dilihat sama dan mendominasi pemikiran para arsitek zaman itu sehingga ketika ditarik sebuah benang merah pada rancangan para arsitek zaman itu dapat dilihat adanya penerapan prinsip tersebut dalam unsur fungsi, ekspresi dan teknologi bangunan.

Berdasarkan pronsip-prinsip ini disimpulkan ada 7 faktor / variabel yang menjadi prinsip penting para arsitek pada zaman modern yang menjadi tolok ukur dan pedoman dalam merancang bangunannya.

\section{Listing}

Pengelompokan merupakan langkah pertama dan fundamental dalam pencapaian arsitektur modern. Bruno Zevi mengkritik prinsip arsitektur classic dimana para arsitek merancang berdasarkan modul, pemahaman yang ia angkat dalam invariabel ini adalah dalam arsitektur tiap bagian memiliki fungsi yang berkesinambungan dengan tujuan dan makna dari bagian itu, bahwa tiap bagian memiliki spesifikasi khusus dan tidak bsa disamakan satu sama lain, maka dalam merancang bangunan diharuskan untuk memahami fungsi yang terjadi pada bangunan itu. tiap ruang pasti memiliki nama yang mengidentifikasikannya, maka dari identfikasi itu ia punya sebuah fungsi yang spesifik dan akan berfungsi sesuai tujuan ketika ditanggapi secara spesisifik juga.

\section{Asymetry}

Bila kita menarik kembali garis sejarah arsitektur dan melihatnya dalam sebuah museum maka kita akan melihat banyak bangunan di zaman klasik yang simetris. Ini merupakan salah satu intensi arsitek di masa itu untuk mengejar estetika dimana kebanyakan bangunan simetris. Perihal tersebut adalah sesuatu yang sangat di hindari dalam prinsip perancangan arsitektur modern. Bruno Zevi melihat tindakan merancang bangunan yang simetris sebagai sesuatu yang tabu dan bentuk kerja seorang arsitek yang malas.

Adanya perbedaan dari fungsi ruang keluarga dan ruang tidur pengakibatkan luas ruang serta bentuk ruang yang berbeda dan tidak bisa disamakan. Ruang keluarga biasanya digunakan untuk jumlah orang yang lebih banyak sementara ruang tidur digunakan untuk individu, dari itu saja kita dapat menyimpulkan besaran ruang yang sama akan mengakibatkan kerugian terhadap ruang tidur yang terlalu luas, ruang tersebut akan terbuang begitu saja.

\section{Anti-Perspective}

Salah satu prinsip yang dianggap salah lagi oleh Bruno Zevi adalah teknik penggambaran ruang 3 dimensi menggunakan perspektif. Ia memandang bahwa teknik yang digunakan pada arsitek masa classic ini adalah upaya yang membatasi kreativitas para arsitek. Dengan diterapkannya penggambaran ruang menggunakan teknik perspektif ini para arsitek dibatasi oleh sebuah box, dimana untuk menggambarkan bentuk yang organik ia terbatas untuk menarik batasan sesuai garis horizon, dapat dikatakan juga bahwa jutru intensi arsitek untuk merancang sesuatu yang bersifat organik hilang. 


\section{Decompostition}

Teori De stijl merupakan suatu upaya yang koheren dalam arsitektur modern. Teknikteknik yang dilakukan dengan menguraikan bentuk tiga dimensional menjadi bidang bidang planar, yang terdiri atas : bidang plafon, empat bidang dinding, dan bidang lantai, sehingga dekomposisi menghasilkan bentuk yang lebih fluid. Tidak hanya bentuk yang lebih fluid, dengan memberikan jarak antar bidang, mengijzinkan cahaya masuk menerangi setiap sudutsudut ruang yang gelap.

Masing-masing bidang planar yg telah berdiri sendiri kemudian dimainkan dengan menggeser posisinya atau menambahkan panjang bidang pada perimeternya, maka sekarang bidang-bidang tidak lagi terjebak dalam kotak yang terbatas. Hal yang sederhana namun belum pernah terpikirkan sebelumnya, upaya ini merupakan langkah yang menentukan dalam emansipasi arsitektur. Kualitas static klasik telah digantikan dengan visi dinamis, dengan penambahan elemen waktu atau dimensi ke 4.

\section{Structure}

Arsitektur merupakan bidang yang berkembang seiring dengan teknologi, namun teknologi tersebut juga terbentuk berdasarkan daya imajinasi manusia serta kemampuan manusia untuk memikirkan yang tidak mungkin. Pada bangunan arsitektur klasik, pemikiran para arsitek terpaku pada kemungkinan bangunan yang akan berdiri berdasarkan struktur yang menopangnya, penyaluran beban yang dibayangkan pada waktu itu dibatasi oelh teknologi yang berkembang pada maanya.

Namun pada arsitektur modern sudah banyak kemungkinan yang terjadi, bahwa struktur tidak di distribusi secart vertikal dan horizontal berdasarkan gaya dorong bumi dan gravitasi yang menjadi unsur utama dalam pembatas rtancangan rtancangan yang lebih berani menantangnya.

\section{Space}

Dalam mendefinisikan invariabel ini Bruno Zevi menggambarkan bahwa bangunan arsitektur modern harus lebih memahami tentang manusia. bahwa para arsitek klasik yang terbiasa merancang sebuah ruang yang berbentuk persegi untuk para pengguna bangunan. Seperti pada bangunan bangunan masa lalu, parthenon merupakan sebuah gubahan arsitektur dengan ruang kosong saja, disitu manusia ditekankan untuk dapat berkegiatan dan mendefinisikan kegiatannya sendiri menggunakan batas batas imajiner. Padahal kegiatan manusia tentunya berbagai macam dan tidak dapat disamakan.

Bangunan bangunan arsitektural di masa lalu terlalu banyak yang memfokuskan diri terhadap bentuk terutama bentuk-bentuk dasar tanpa memperhatikan tujuan dari pembentukan tersebut. Tanpa batasan batasan, mereka dapat melakukan kegiatan dengan cara apa saja tanpa memperhatikan ruang yang sudah disediakan, sehingga tidak ada relasi antara bangunan dengan penggunanya.

\section{Reintegration}

Bangunan modern tentunya juga memperhatikan kontaks lingkungannya. Terutama di lingkungan urban bangunan bangunan modern berdiri di tapak yang sudah ada lingkungan eksisting dari lingkungan alam hingga integrasi dengan bangunan yang sudah ada sebelumnya menjadi aspek penting yang diperhatikan.

Kebanyakan arsitek klasik berpikir bahwa sebuah bangunan menjadi objek yang berdiri sendiri, tanpa memperhitungkan seberapa besar kontribusi bangunan terhadap lingkungan sekitarnya. Bangunan tentunya memiliki dampak terhadap lingkungan sekitarnya, cara menghubungkan sebuah bangunan menjadi aspek yang penting karena bangunan yang 
berdiir sendiri akan menjadi sebuah objek yang asing dan tidak harmonis terhadap lingkungan sekitarnya.

Hubungan bangunan tidak dilihat berdasarkan hubungannya dengan objek lain namun dalam objek bangunan itu sendiri ia memiliki keterhubungan, misalnya hubungan antar saru ruang dengan ruang lain yang menyebabkan adanya interaksi pada fisik bangunannya.

\subsection{KAJIAN TEORI}

Dari kajian teori yang didapat peneliti dapat disimpulkan bahwa dalam bangunan gedung Pasca-Sarjana Universitas Katolik Parahyangan yang dirancang oleh Mohammad Soesilo tentunya berdasar pada tiga prinsip sebagai bangunan yang baik, namun adanya tujuh variabel prinsip perancangan arsitek modern mempengaruhi perancangan Mohammad Soesilo dalam mencapai ketiga unsur good building dalam karya rancangannya, sehingga dalam penelitian ini dilengkapi dengan sebuah matriks yang merupakan penjelasan tentang pengaruh ketujuh variabel arsitektur modern terhadap prinsip perancangan good building untuk memperjelas pancarian pengaruh dari kedua prinsip tersebut terhadap aplikasi perancangan Mohammad Soesilo pada gedung Pasca Sarjana Universitas Katolik Parahyangan.

\subsection{KESIMPULAN TEORI}

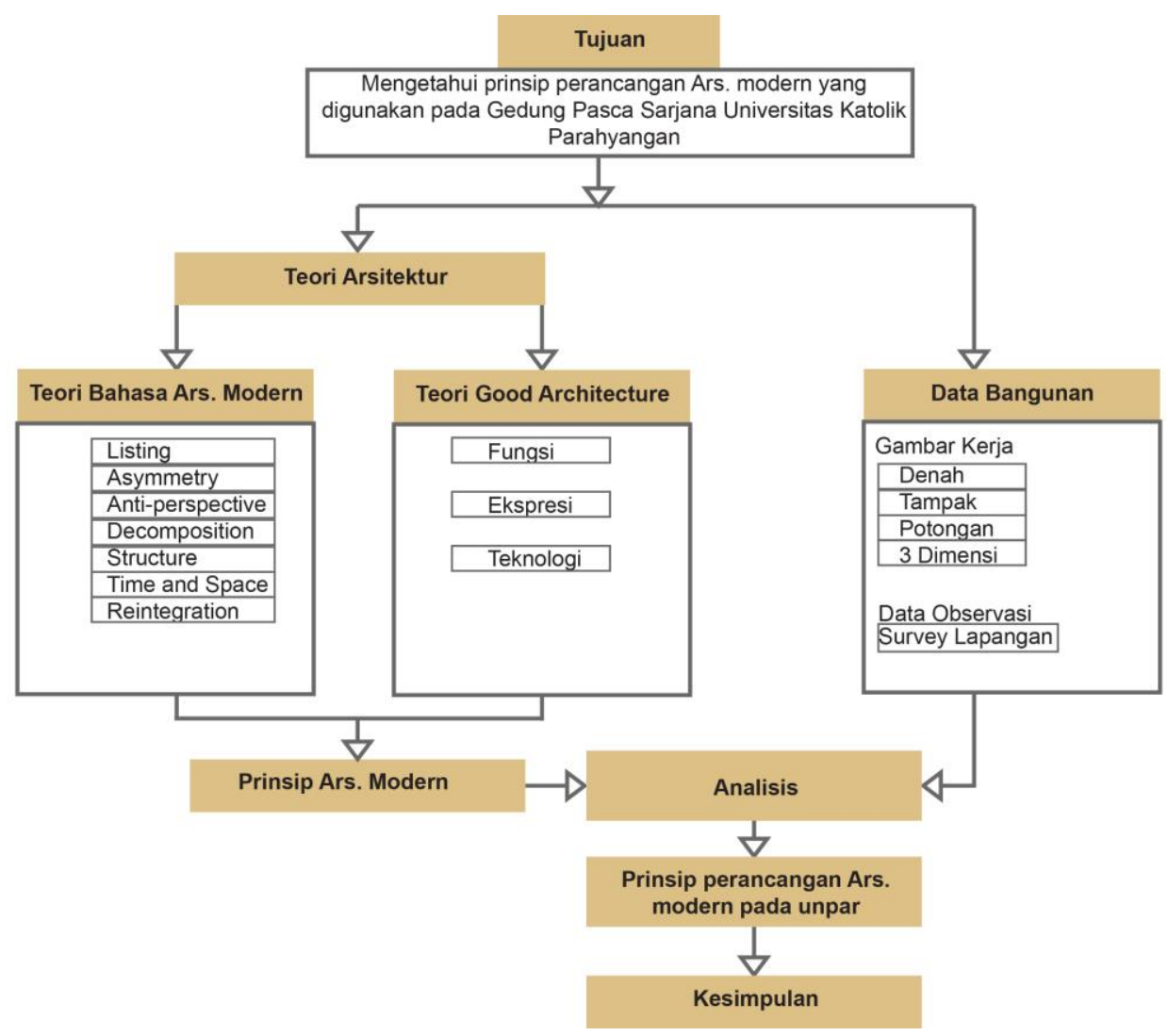

Figur 2. Kerangka Teori 
Tabel 1. Matriks Prinsip Perancangan Arsitektur Modern

\begin{tabular}{|c|c|c|c|}
\hline & Fungsi & Ekspresi & Teknologi \\
\hline Listing & $\begin{array}{l}\text { Adanya pengelompokan } \\
\text { terhadap Ruang }\end{array}$ & $\begin{array}{l}\text { Bentuk bangunan mampu } \\
\text { menggambarkan Fungsi }\end{array}$ & $\begin{array}{l}\text { Struktur mengakomodasi } \\
\text { kesatuan bangunan }\end{array}$ \\
\hline Asymetry & $\begin{array}{l}\text { Bentuk bangunan yang } \\
\text { definitive }\end{array}$ & $\begin{array}{l}\text { Hilangnya sifat bangunan } \\
\text { yang modular }\end{array}$ & $\begin{array}{l}\text { Struktur yang tidak } \\
\text { modular }\end{array}$ \\
\hline Anti-Perspective & $\begin{array}{l}\text { Adanya keterbatasan jarak } \\
\text { untuk fungsi tertentu }\end{array}$ & $\begin{array}{l}\text { Tiap sudut pandang } \\
\text { terhadap bangunan } \\
\text { meberikan kesan yang } \\
\text { berbeda }\end{array}$ & - \\
\hline Decomposition & $\begin{array}{l}\text { Hilangnya persepsi ruang } \\
\text { yang berbentuk kubus }\end{array}$ & $\begin{array}{l}\text { Ruang yang terbentuk } \\
\text { oleh bidang planar dan } \\
\text { garis }\end{array}$ & - \\
\hline Structure & $\begin{array}{l}\text { Struktur yang definitif } \\
\text { terhadap kegiatan }\end{array}$ & $\begin{array}{l}\text { Kejujuran struktur pada } \\
\text { bangunan }\end{array}$ & $\begin{array}{l}\text { Struktur yang mampu } \\
\text { menngambarkan } \\
\text { perkembangan teknologi } \\
\text { zaman modern }\end{array}$ \\
\hline Space & $\begin{array}{l}\text { Bentuk ruang yang } \\
\text { mendukung kegiatan }\end{array}$ & $\begin{array}{l}\text { Bentuk ruang yang } \\
\text { menggambarkan sifat } \\
\text { kegiatannya }\end{array}$ & $\begin{array}{l}\text { Struktur yang sesuai guna } \\
\text { kegiatan ruang }\end{array}$ \\
\hline Reintegration & $\begin{array}{l}\text { Ada sistem sirkulasi yang } \\
\text { menghubungkan } \\
\text { keseluruhan bangunan }\end{array}$ & $\begin{array}{l}\text { Adanya transisi yang jelas } \\
\text { pada system sirkulasi } \\
\text { bangunan }\end{array}$ & $\begin{array}{l}\text { Teknologi sirkulasi yang } \\
\text { mampu menghubungkan } \\
\text { bangunan }\end{array}$ \\
\hline
\end{tabular}

\section{ANALISA}

\subsection{GEDUNG PASCA-SARJANA UNIVERSITAS KATOLIK PARAHYANGAN}

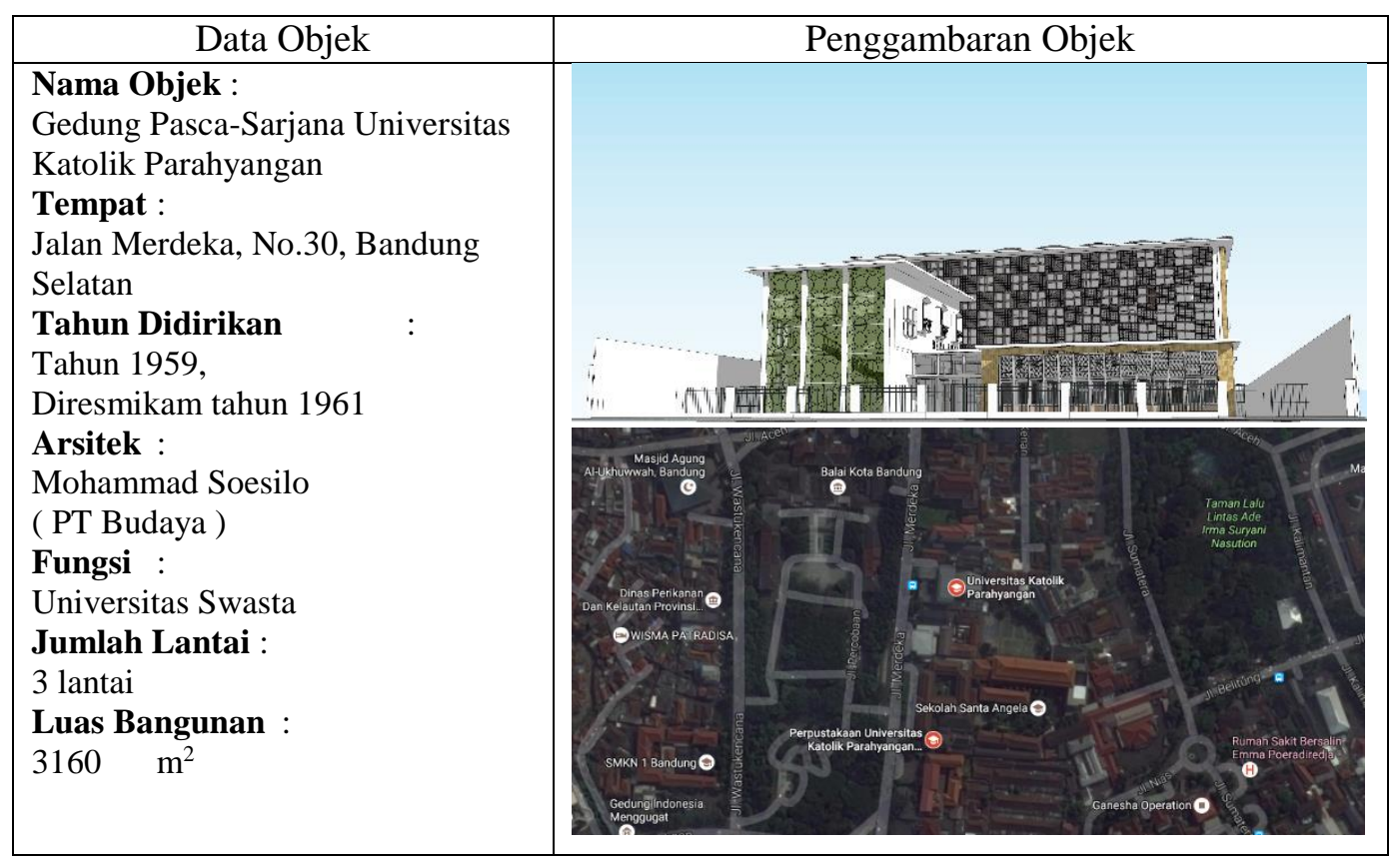

\subsection{MOHAMMAD SOESILO}

Mohammad Soesilo (Alm) salah satu tokoh perintis perencana kota di Indonesia merupakan salah satu arsitek pertama di Indonesia, ia salah satu arsitek yang memiliki ijazah Arsitek locale belangen (pada masanya ijazah arsitek yang berlaku secara sah). Ia pindah ke bandung ketika dipanggil oleh bapak Thomas Karste untuk membantunya pada sebuah 
proyek pembangunan. Berkat dukungannya oleh Thomas Karste sampai ia memperoleh posisinya di dinas pekerjaan Umum Kota. Ia Pindah ke Jakarta pada tahun 1939.

Mohammad Soesilo ditunjuk oleh yayasan Universitas katolik Parahyangan yang didukung oleh keuskupan bandung untuk merencanakan ulang bangunan yang berdiri di jalan merdeka, awalnya disebut sebagai gedung panti Budaya dan merancangnya menjadi sebuah kampus ketika munculnya kebutuhan pengembangan dari universitas tersebut. Setelah adanya tender dilakukan ada 3 karya yang diseleksi oleh yayasan Universitas Katolik parahyangan dan keuskupan dan pada akhirnya terpilih karya rancangan Soesilo untuk direalisasikan sebagai bangunan yang direncanakan itu.

Karya Soesilo awalnya hampir dikalahkan oleh karya seseorang arsitek yang merancang bangunan kampus mirip dengan kampus Universitas Gajah mada Yogyakarta, namun karya Soesilo pada saat itu dipilih karena menggambarkan semangat zaman arsitekturnya dan dirasa merupakan karya yang paling dapat bertahan ekspresi gayanya untuk era era kedepannya. Perihal tersebut dibuktikan ketika setelah 50 tahun berdiri bangunan Universitas Katolik Parahyangan tidak diubah sedikitpun dan diresmikan sebagai bangunan cagar budaya.

Pada Tahun 1965 akhirnya Soesilo memutuskan untuk mengakhiri karirnya di PT Budaya dan menyerahkan tanggung jawab serta posisinya sebagai direktur pada anaknya Suhartono Susilo, namun karya karya Soesilo selama hidupnya menjadi bukti sejarah arsitektur dan sebagai salah satu karakteristik gaya arsitektur lokal terutama pada zaman pasca kemerdekaan.

\subsection{SEJARAH}

Universitas Katolik Parahyangan pada awalnya berdiri di jalan aceh tepatnya di bangunan Panti Budaya, aats kebutuhan penambahan ruang perkuliahan akhirnya dipindahkan ke kampus yang sekarang berdiri di jalan merdeka no.32 (sekarang no.30). Sebelumnya gedung panti Budaya ini dapat mencukupi kebutuhan ruang dan fasilitas untuk perkuliahan yang awalnya hanya memiliki satu program studi yaitu program studi ekonomi, lalu terjadi pengembangan kampus dengan didirikannya fakultas hukum sehingga gedung Panti Budaya tidak lagi dapat mencukupi kebutuhan perkuliahan sehingga dengan dukungan keuskupan katolik Bandung akhirnya bangunan tambahan dibangun kembali dengan rencana gedung berlantai 3 di jalan Merdeka.

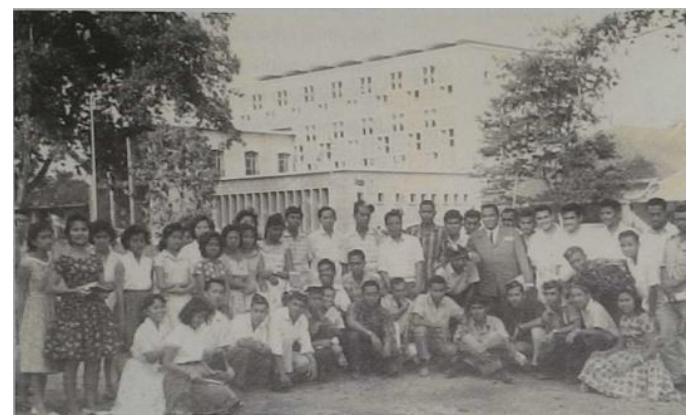

Figur 3. depan bangunan Gedung Pasca-Sarjana Universitas Katolik Parahyangan (Sumber: Kenang kenangan 50th Universitas Katolik Parahyangan)

Beberapa upaya dalam memugar bangunan ini sudah terjadi, namun tidak ada perubahan yang signifikan dari bentuk bangunan. Pemugaran yang terjadi hanya perubahan material penutup lantai dari bahan yang awalnya ubin menjadi marmer, Cat yang pada awalnya hanya menggunakan pemutih dari kapur kini sudah dilapis dengan cat, serta perawatan perawatan kecil pada bangunan yang tidak signifikan. Tidak banyak yang dipugar 
karena sudah menjadi bagian dari peraturan pemerintah bahwa bangunan ini harus di preservasi dengan keadaan seorsinil mungkin.

\subsection{DESKRIPSI}

Bangunan merupakan kampus kepemilikan swasta ( Yayasan Universitas Katolik Parahyangan ), kurikulum universitas merupakan kurikulum dengan mata perkuliahan standar DIKTI yang diterapkan menggunakan nilai nilai dasar pembelajaran universitas katolik. Gedung Pasca Sarjana Universitas Katolik Parahyangan merupakan gedung kampus studi Pasca Sarjana (sarjana strata 2), menjadi pusat / kantor doktoral Universitas katolik Parahyangan.

Bangunan terletak di jalan merdeka merupakan wilayah pusat kota. Di lingkungan sekitar bangunan terdapat Balai kota bandung yang membuatnya menjadi kawasan cagar budaya karena banyaknya bangunan heritage di sekitar tapak.

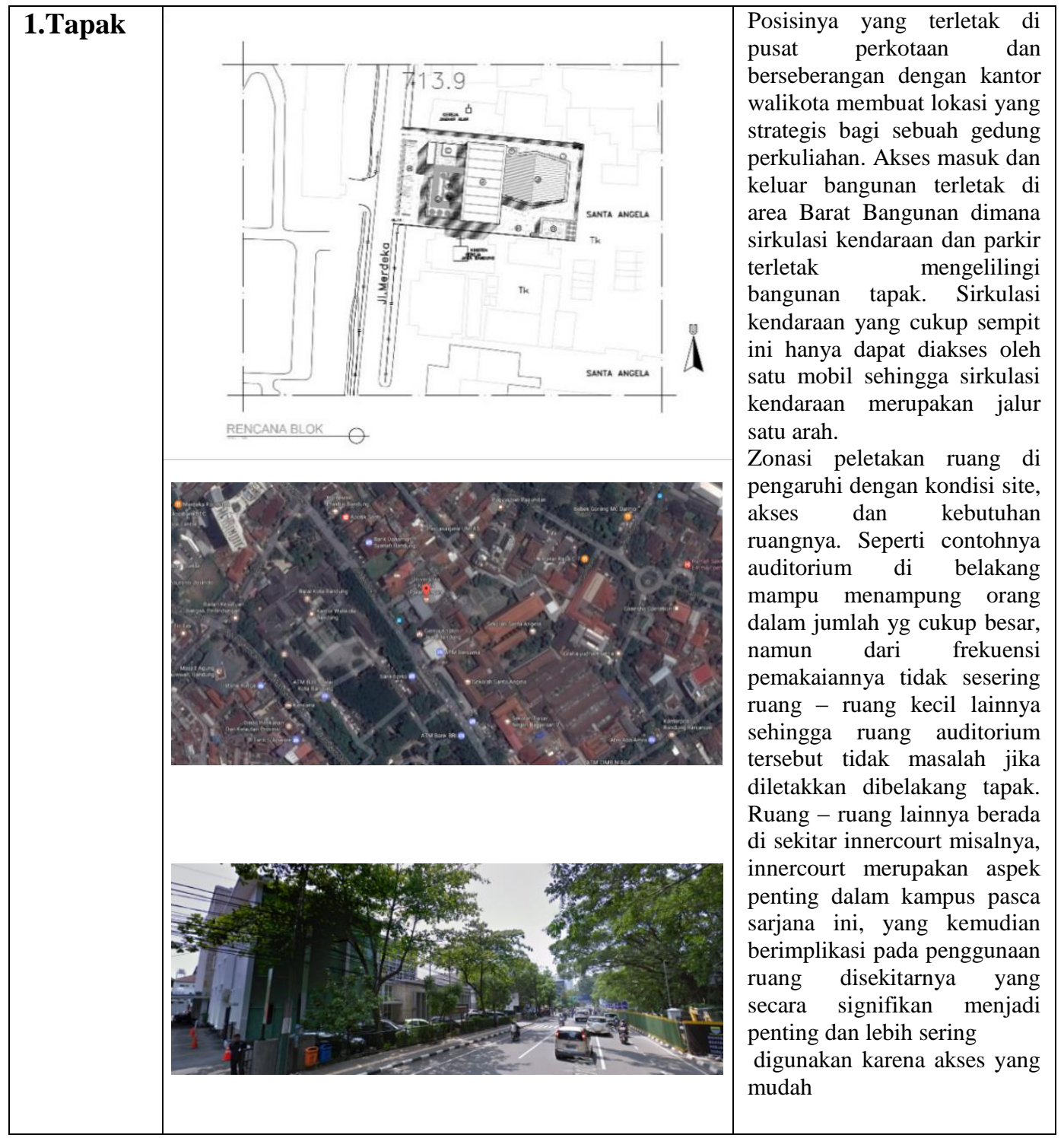




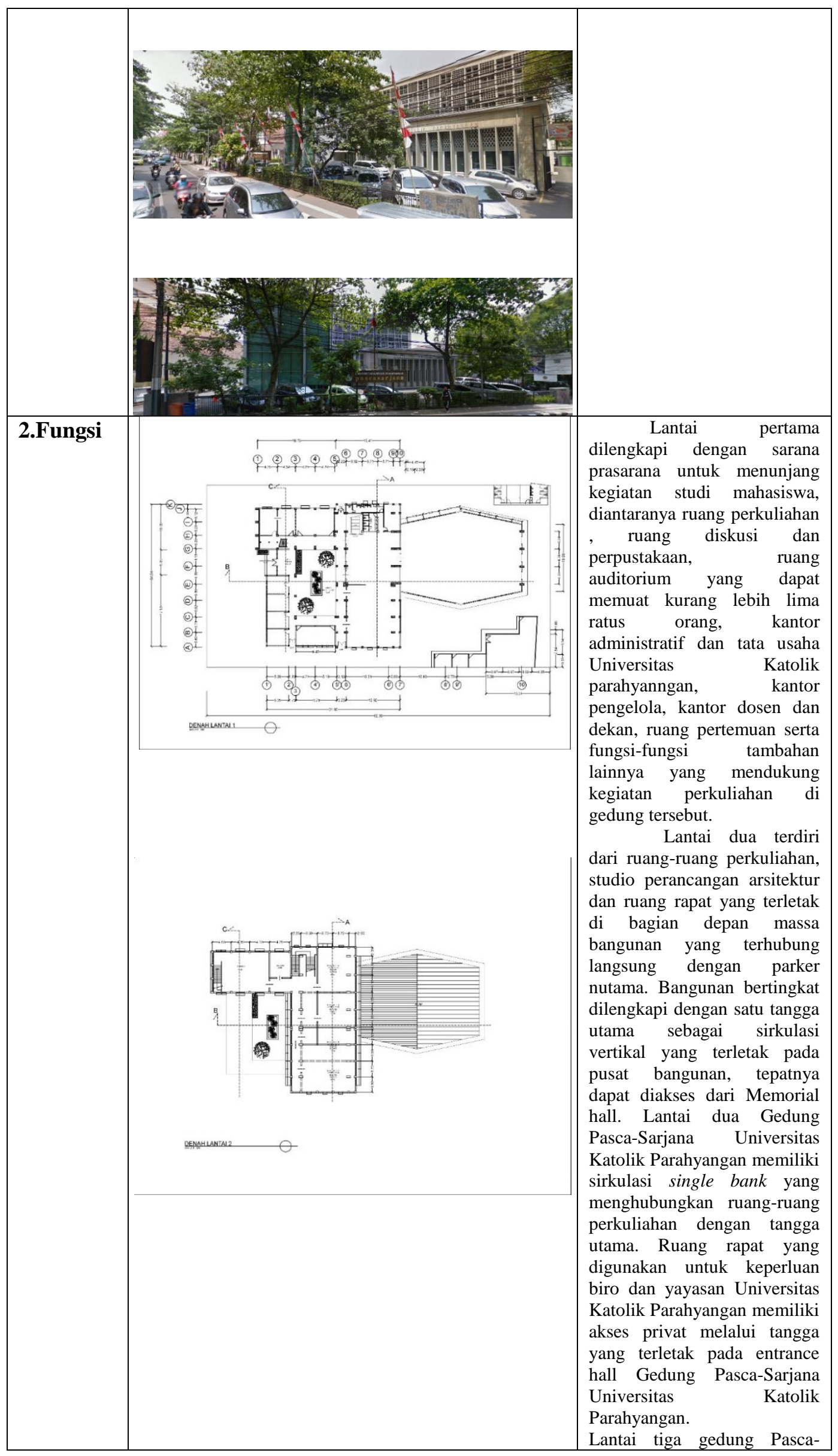




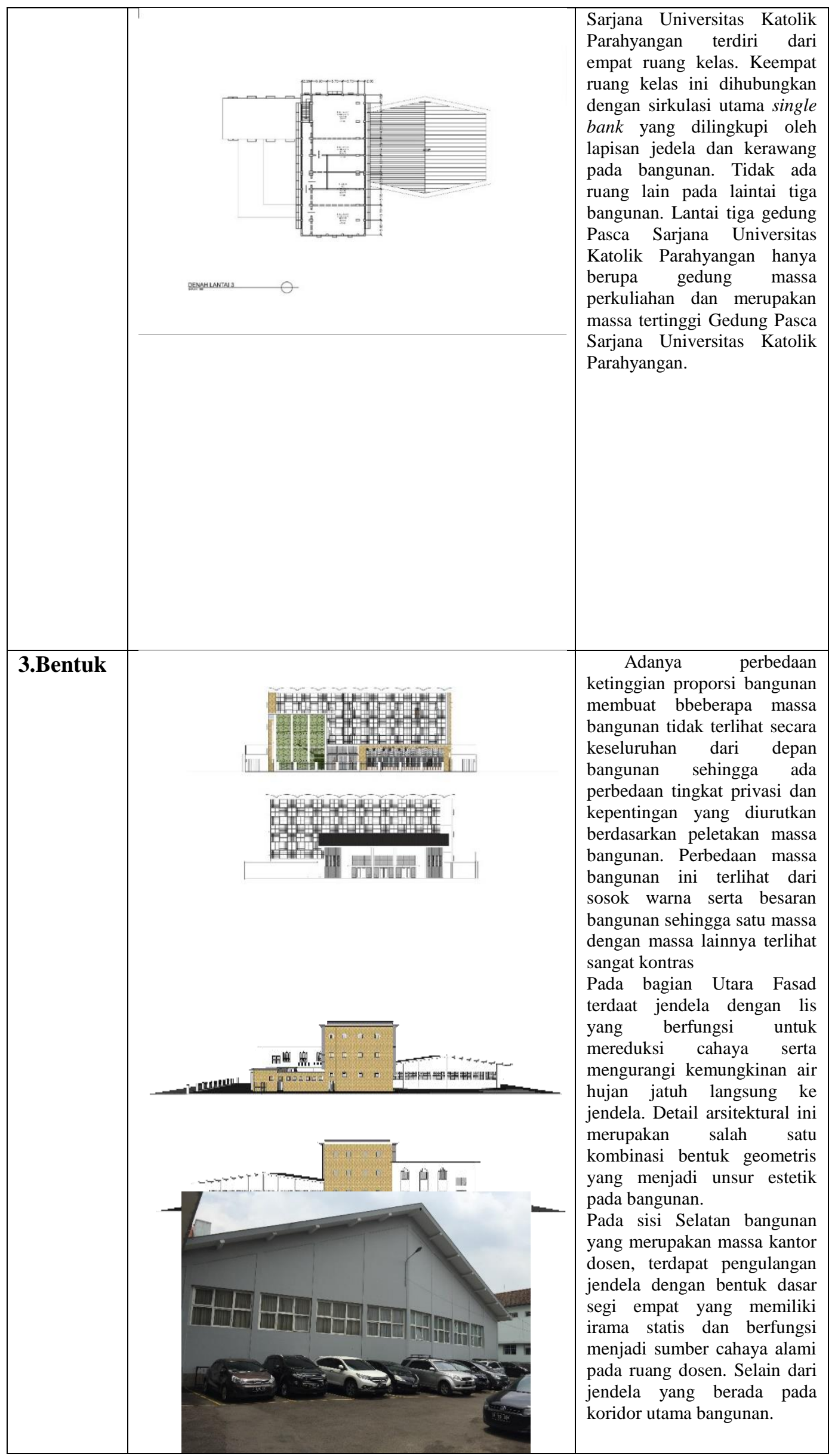


The principles of modern architectural design as observed in...

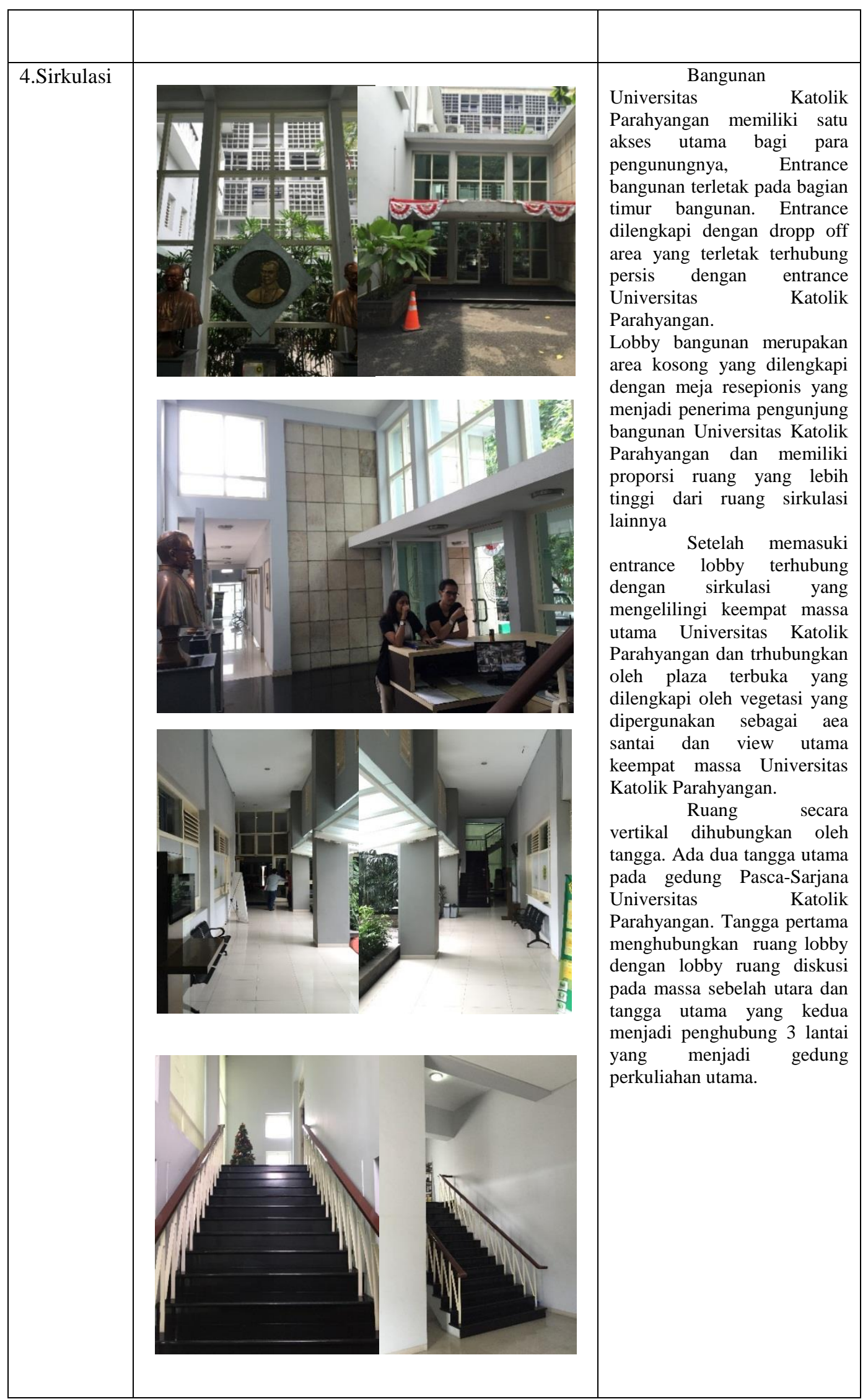




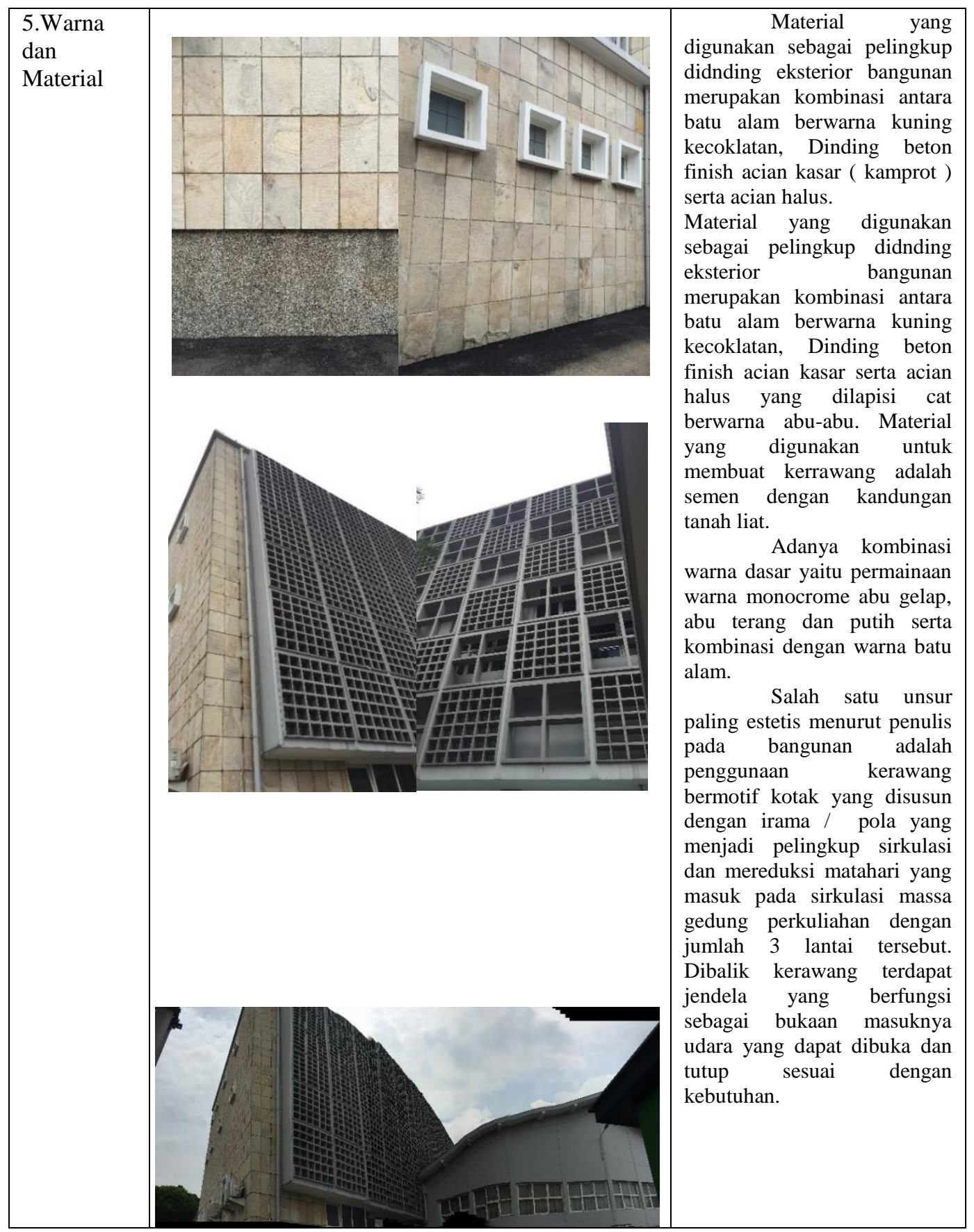

\subsection{ANALISA}

\section{Listing}

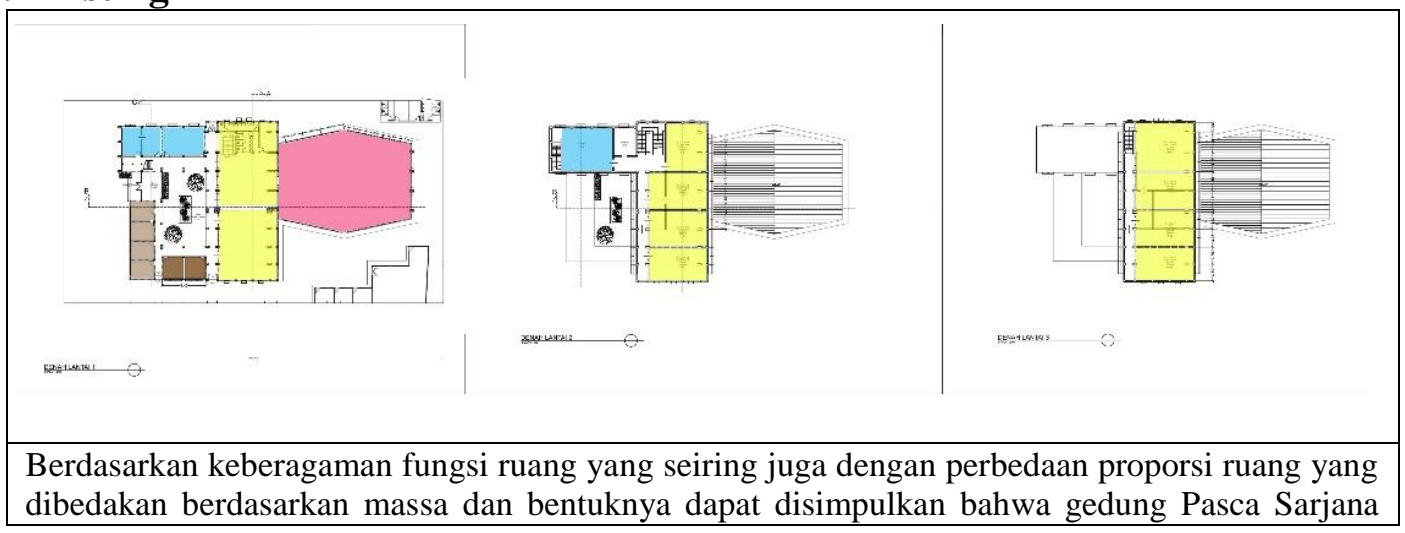




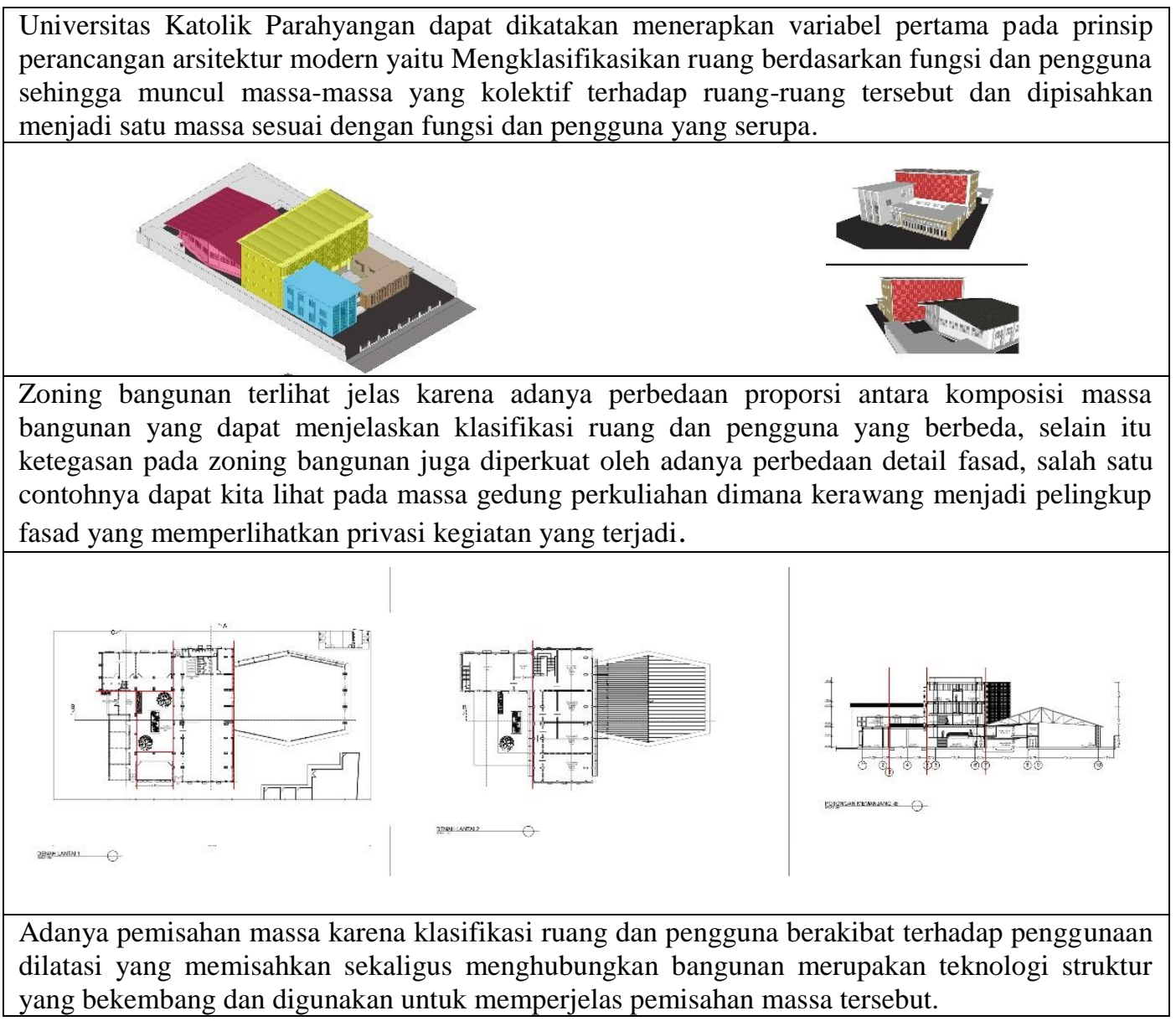

\section{Asymetry}

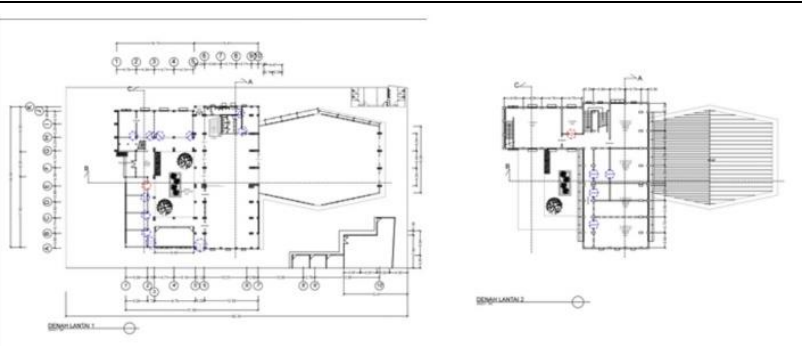

Dapat dikatakan bahwa bangunan ini tidak simetris karena setelah analisa yang kita lihat secara horizontal dan vertikal bangunan ini keseluruhan bangunan tidak memiliki komposisi yang seimbang disebabkan karena adanya perbedaan fungsi dan kegiatan pada ruang yang mendefinisikan bentuk. Walaupun proporsi tiap ruang dapat dibagi rata namun adanya peletakan pintu mengubah persepsi pengguna ruang secara imajinatif sehingga ruang tidak terasa terbagi dua.
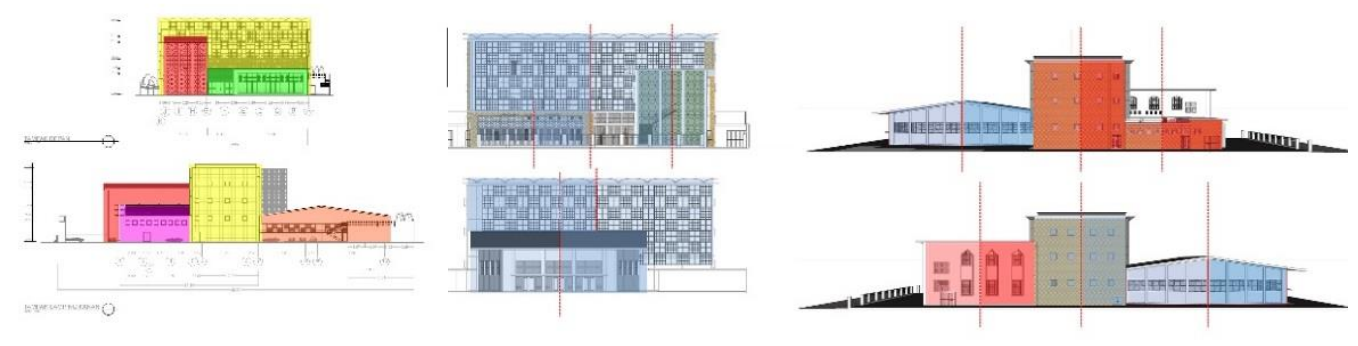

Bangunan yang tidak simetris mampu memperlihatkan ekspresi keberagaman aktivitas pada bangunan yang berbeda sehingga tidak diberlakukan perancangan massa yang simetris. Namun 
masih ada unsur simetri pada beberapa bagian fasad bangunan ketika bangunan dipisahkan berdasarkan klasifikasi massanya.

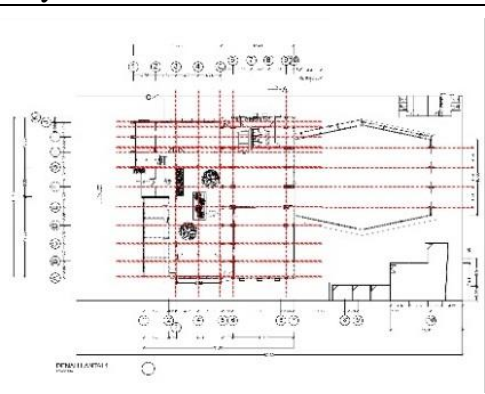

Adanya kemajuan dalam pendidikan pembangunan dapat dilihat dari bangunan yang secara struktural aplikasinya sudah cukup kompleks. Perbedaan grid pada bangunan merupakan salah satu cerminan dimana adanya kemajuan di teknologi struktur yang menggunakan perhitungan yang kompleks.

\section{Anti-Perspective}

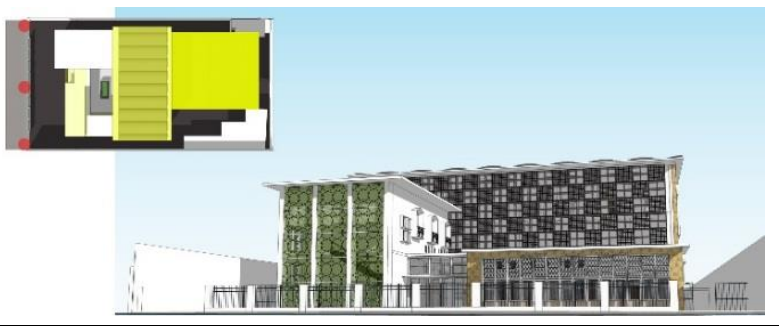

Pencapaian fungsi bangunan dapat dilihat dari adanya pengolahan bentuk lebih lanjut dari bentuk balok, dimana sifat ruang yang linear sudah mampu mengakomodasi kegiatan pada ruang auditorium, Adanya penempatan yang berpengaruh terhadap keterbatasan titik pandang terhadap bangunan.
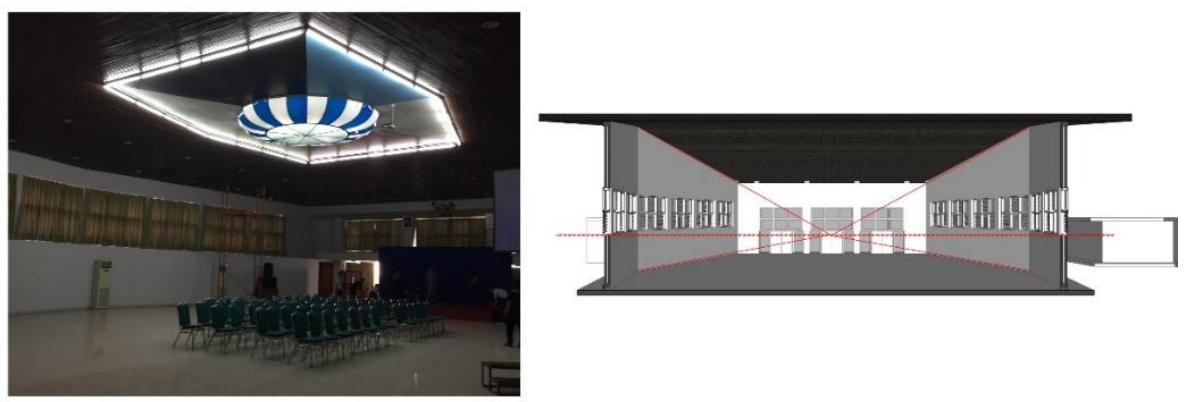

Dapat dikatakan bahwa gedung pasca sarjana universitas katolik parahyangan menggunakan teknik yang tidak tergantung pada penggambaran perpektif sehingga bangunan tidak lagi dikatakan sebagi bangunan yang kaku / terikat pada grid. hal ini dibuktikan dengan adanya massa adisi auditorium yang merupakan gubahan bentuk segitiga dan trapesium.

\section{Decomposition}

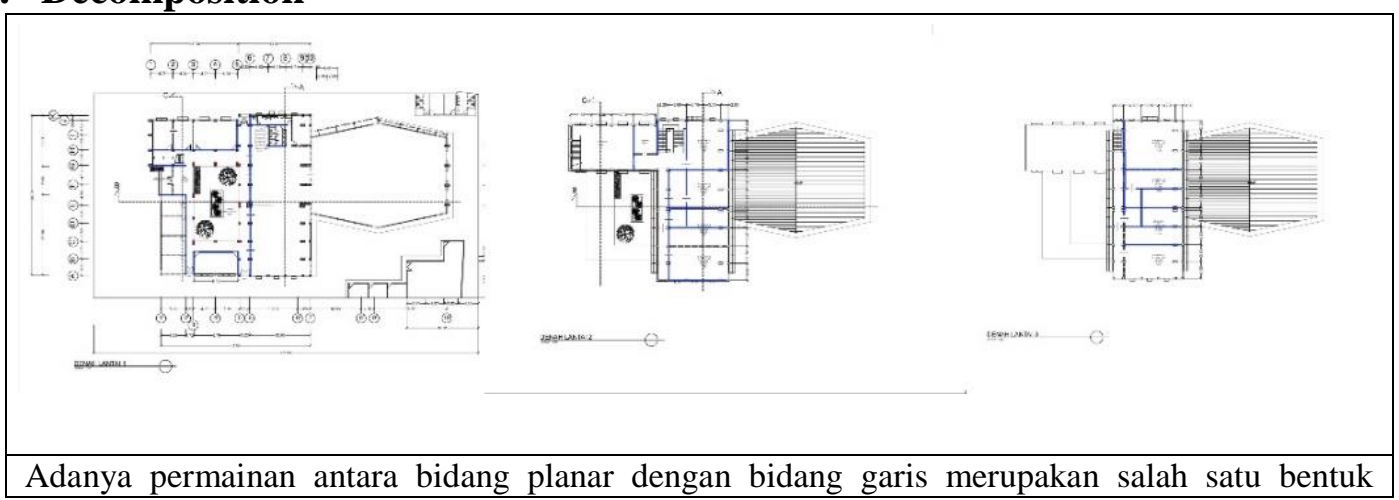


pencapaian hubungan antara ruang, dimana ruang tidak lagi dideterminasi oleh sebuah bidang yang massive, keterbukaan bangunan dan hubungan dengan ruang terbuka lebih terasa bagi para pengunjung
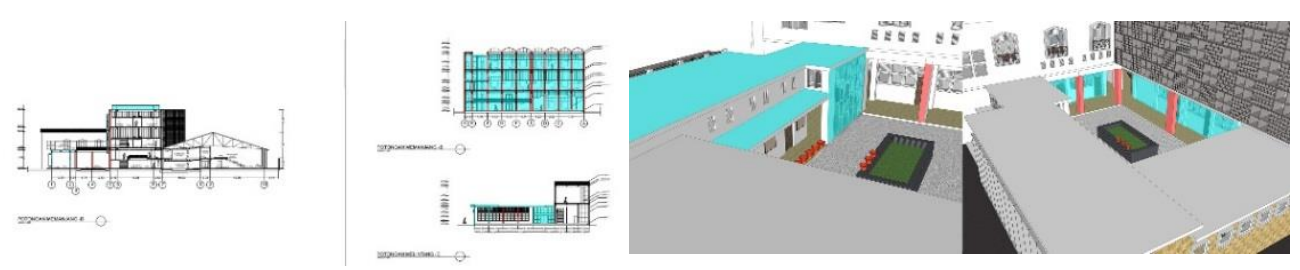

Pada gedung pasca sarjana universitas katolik parahyangan terdapat kombinasi antara ruang ruang yang sifatnya terbuka dan tertutup, dalam menerapkan kombinasi ini perancang mengkombinasikan adanya permainan bidang yang tidak di dominasi oleh sbuah bidang yang tertutup saja namun ada beberapa jenis bidang yang dipermainkan dengan hubungan tidak terikat satu sama lain sehingga kesan kotak / ruang kubus pada bangunan hilang.

\section{Structure}

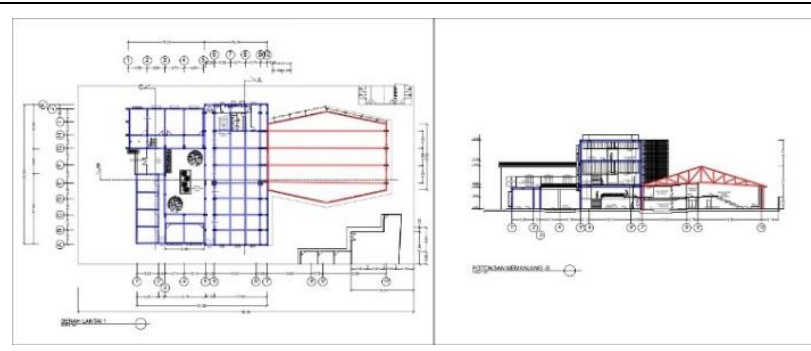

Adanya variasi sitem struktur yaitu Penggunaan struktur rigid fram e dan struktur bentang lebar menggunakan truss merupakan determinasi struktur yang ditentukan oleh fungsi. Penggunaan struktur bentang lebar untuk mencapai fungsi kegiatan di audiotorium merupakan salah satu cerminan bentuk aplikasi kemajuan struktur bangunan pada zaman tersebut. Dimana belum terlalu banyak bangunan bentang lebar yang menggunakan struktur baja.

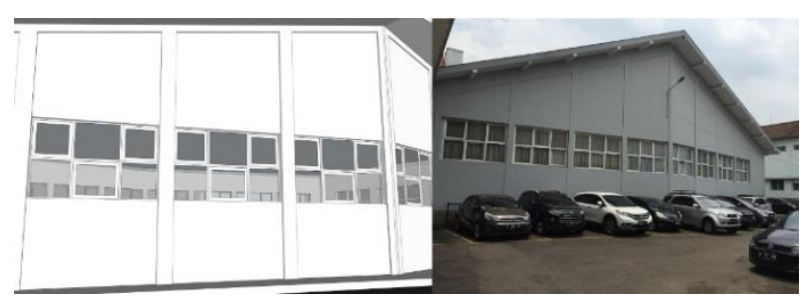

Ekspresi bangunan yang pilotis merupakan salah satu bentuk pencapaian ekspresi bangunan yang didukung oleh adanya teknologi pada zaman tersebut untuk mencapainya. Bangunan yang massive terlihat ditumpu oleh kolom-kolom yang merupakan elemen garis vertikal sehingga muncul kesan melayang pada bangunan

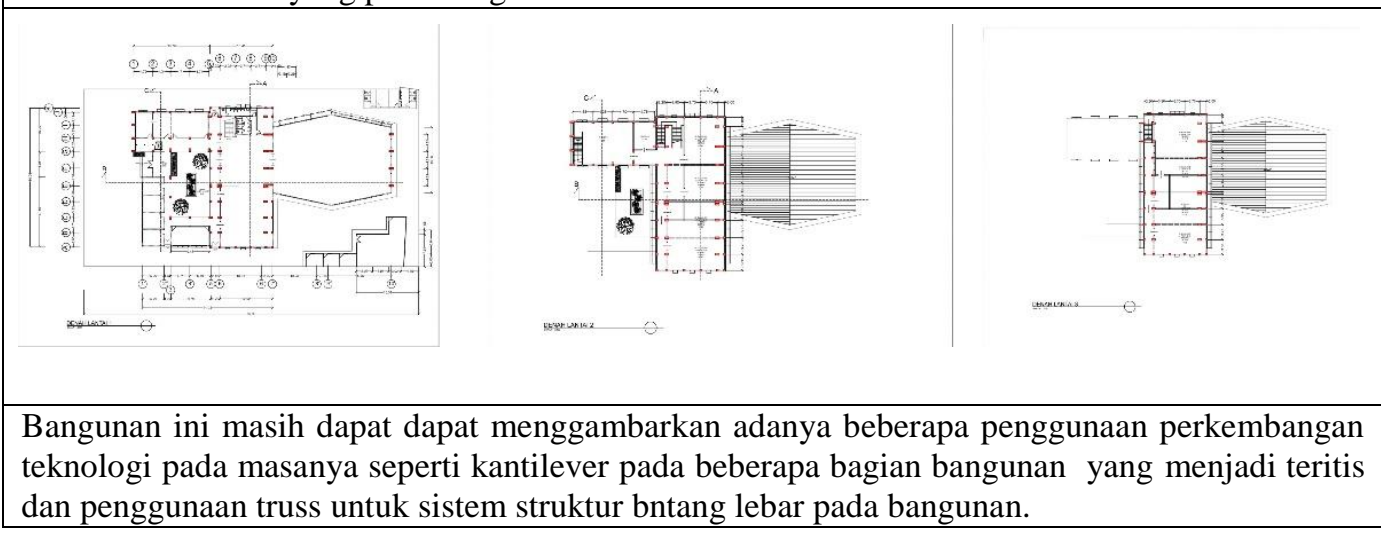




\section{Space}

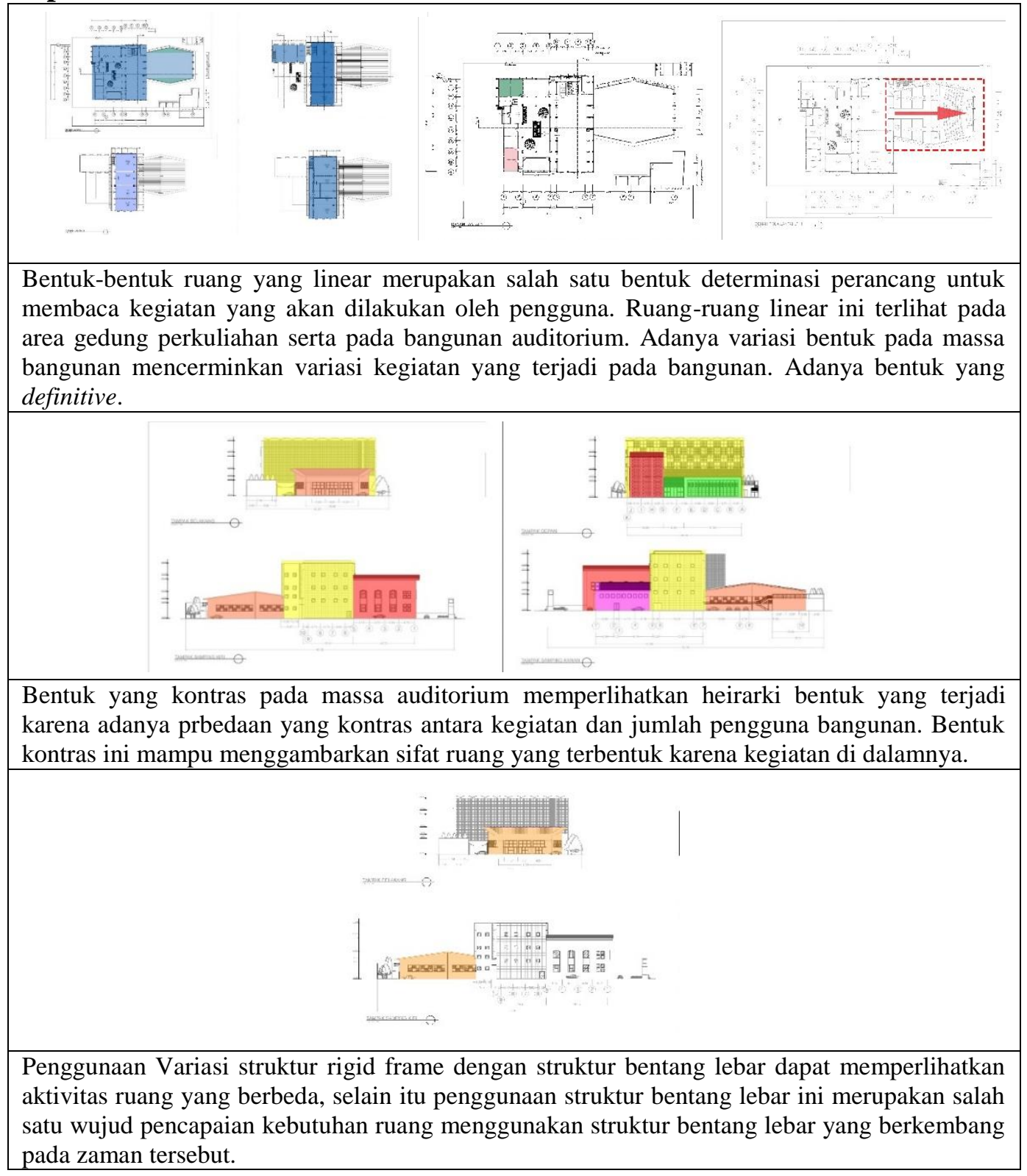

\section{Reintegration}

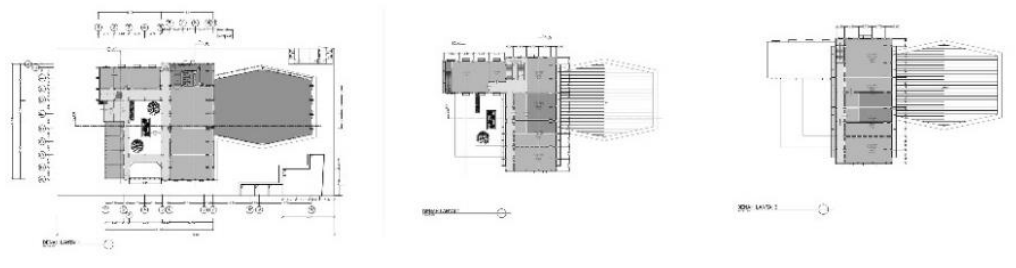

Hubungan antara ruang sudah terkoneksi secara baik, adanya elemen elemen pedukung yang tegas dan berfungsi dengan baik mendukung integrasi bangunan secara keseluruhan walaupun bangunan memiliki massa yang terpisah msehingga bangunan memiliki kejelasan sistem sirkulasi dan titik titik yang menjadi elemen penghubung sirkulasi bangunan. 


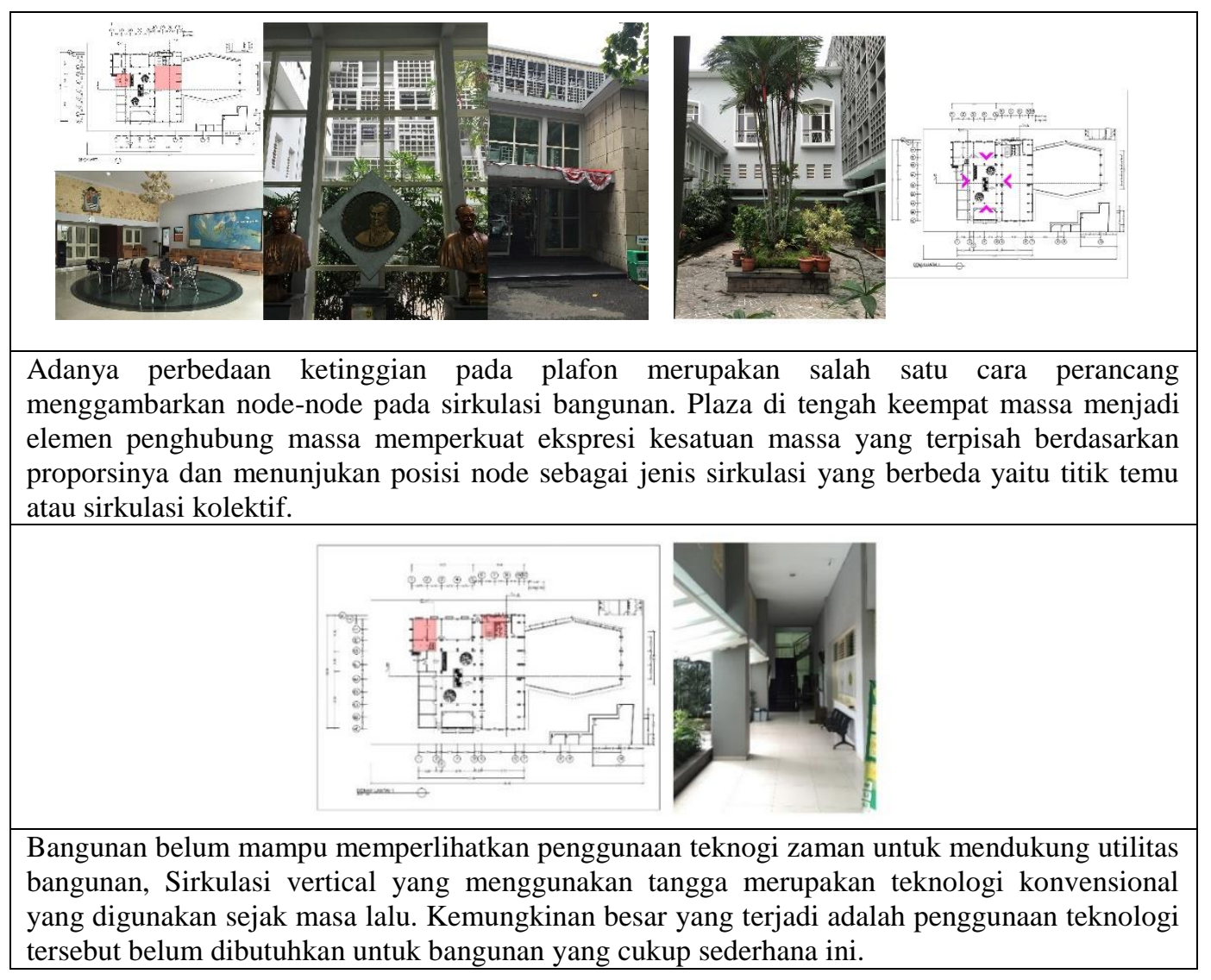

\section{Kesimpulan Analisis}

Tabel 2. Matriks pencapaian gedung Pasca-Sarjana Universitas Katolik Parahyangan sebagai arsitektur modern

\begin{tabular}{|c|c|c|}
\hline Prinsip Arsitektur Modern & Checklist & Keterangan \\
\hline \multicolumn{3}{|c|}{ Listing } \\
\hline Fungsi & $\mathrm{v}$ & Adanya pengelompokan ruang berdasarkan klasifikasi \\
\hline Ekspresi & $\mathrm{v}$ & $\begin{array}{l}\text { Ekpresi massa bangunan yang menggambarkan } \\
\text { keberagaman fungsi }\end{array}$ \\
\hline Teknologi & $\mathrm{v}$ & Penggunaan dilatasi pada system struktur bangunan \\
\hline \multicolumn{3}{|c|}{ Asymetry } \\
\hline Fungsi & $\mathrm{v}$ & Ruang yang terbentuk menjadi definitive dan efisien \\
\hline Ekspresi & $\mathrm{v}$ & Ekspresi massa yang definitive terhadap fungsi \\
\hline Teknologi & $\mathrm{v}$ & Grid yang tidak modular pada bangunan \\
\hline \multicolumn{3}{|c|}{ Anti-Perspective } \\
\hline Fungsi & $\mathrm{v}$ & $\begin{array}{l}\text { Adanya pembagian zona privat dan publik terhadap } \\
\text { penempatan massa }\end{array}$ \\
\hline Ekspresi & $\mathrm{v}$ & $\begin{array}{l}\text { Titik pandang terhadap keseluruhan bangunan yang } \\
\text { hilang }\end{array}$ \\
\hline \multicolumn{3}{|c|}{ Decomposition } \\
\hline Fungsi & $\mathrm{v}$ & $\begin{array}{l}\text { Dominasi ruang yang bebas dari bentuk dasar } \\
\text { (keterikatan ruang balok) }\end{array}$ \\
\hline Ekspresi & $\mathrm{v}$ & $\begin{array}{l}\text { Ada transisi ruang yang jelas akibat permainan bidang } \\
\text { planar dan garis }\end{array}$ \\
\hline \multicolumn{3}{|c|}{ Structure } \\
\hline
\end{tabular}


The principles of modern architectural design as observed in...

\begin{tabular}{|c|c|c|}
\hline Fungsi & $\mathrm{v}$ & $\begin{array}{l}\text { Adanya variasi struktur yaitu rigid frame dan truss } \\
\text { bentang lebar }\end{array}$ \\
\hline Ekspresi & $\mathrm{x}$ & $\begin{array}{l}\text { Beberapa system struktur yang ditutupi elemen } \\
\text { pelingkup }\end{array}$ \\
\hline Teknologi & $\mathrm{v}$ & $\begin{array}{l}\text { Menggunakan struktur kantilever dan system bentang } \\
\text { lebar truss yang menggambarkan teknologi zaman }\end{array}$ \\
\hline \multicolumn{3}{|c|}{ Space } \\
\hline Fungsi & $\mathrm{v}$ & $\begin{array}{l}\text { Bentuk ruang yang bervariasi untuk memenuhi } \\
\text { kegiatan fungsi ruangnya. }\end{array}$ \\
\hline Ekspresi & $\mathrm{v}$ & $\begin{array}{l}\text { Keberagaman bentuk massa bangunan yang terbentuk } \\
\text { oleh definisi kegiatannya }\end{array}$ \\
\hline Teknologi & $\mathrm{v}$ & $\begin{array}{l}\text { Penggunaan system struktur truss bentang lebar untuk } \\
\text { mengakomodasi kebutuhan auditorium }\end{array}$ \\
\hline \multicolumn{3}{|c|}{ Reintegration } \\
\hline Fungsi & $\mathrm{v}$ & $\begin{array}{l}\text { Massa yang terintergrasi oleh system struktur yang } \\
\text { jelas }\end{array}$ \\
\hline Ekspresi & $\mathrm{v}$ & Adanya beberapa tahap transisi pada system sirkulasi \\
\hline Teknologi & $\mathrm{x}$ & Sistem sirkulasi bangunan yang konvensional \\
\hline \multicolumn{3}{|c|}{$\begin{array}{l}\mathrm{v}-\text { Berpengaruh } \\
\mathrm{x}-\text { Tidak Berpengaruh }\end{array}$} \\
\hline
\end{tabular}

\section{PENUTUP}

\subsection{KESIMPULAN}

1. Bagaimana prinsip arsitektur modern diterapkan pada gedung Pasca-Sarjana Universitas Katolik Parahyangan?

Prinsip arsitektur modern diterapkan dengan mengklasifikasikan ruang-ruang dengan fungsi dan pengguna yang serupa, aplikasinya terhadap rancangan bangunan adalah dengan adanya pemisahan massa bangunan berdasarkan klasifikasinya. Massa yang terbentuk memiliki proporsi dan komposisi bentuk yang beragam sehingga ketika dilihat menjadi satu kesatuan simetri bangunan hilang walaupun masih ada beberapa unsur simetri pada fasad bangunan ketika dipisah berasarkan massanya. Massa tersebut disusun berdasarkan kebutuhan zoning yang membedakan pengguna serta tingkat privasi kegiatan massa tersebut sehingga keseluuhan bentuk massa tidak bisa dilihat dari satu titik perspektif.

Adanya permainan antara bidang planar dan bidang garis merupakan salah satu ekspresi bentuk yang mendefinisikan ruang-ruang serta ekspresi pilotis pada banguna terlihat pada beberapa dak beton kantilever bangunan yng juga berfungsi sebagai teritis. Penggunaan sistem struktur kantilever ini juga merupakan cerminan teknologi konstruksi yang berkembang pada masa era tersebut. Adanya variasi sistem struktur rigid frame dengan truss bentang lebar menggambarkan pemilihan struktur yang dapat mengakomodasi kegiatan sesuai dengan spesifikasi ruangnya.

Zoning bangunan diperkuat dengan adanya transisi yang berbeda sesuai karakter kegiatan pada ruang-ruang tersebut. Elemen sirkulasi merupakan transisi utama yang menghubungkan bangunan sehingga pepindahan antar massa bangunan tetap terfasilitasi dan menciptakan ekspresi bentuk yang memiliki kesatuan walaupun terdiri dari komposisi massa yang beragam.

Dalam pencapaian banguanan sebagai sebuah bangunan yang baik klasifikasi terhadap fungsi yang berbeda karena kegiatan dan penggunanya merupakan unsur utama yang mempengaruhi aplikasi perancangan Universitas Katolik Parahyangan. 


\section{Apakah bangunan gedung Pasca-Sarjana Universitas Katolik Parahyangan sesuai dengan kaidah bahasa arsitektur modern?}

Gedung Pasca-Sarjana Universitas Katolik Parahyangan sesuai dengan kaidah bahasa arsitektur modern karena menggunakan prinsip perancangan arsitektur modern yang terlihat pada bentuk fisik bangunan yang dipengaruhi oleh ketujuh variable bahasa arsitektur modern

\section{DAFTAR PUSTAKA}

D.K.Ching, Francis.(1999)Arsitektur: Bentuk, Ruang dan Susunannya. Cetakan ke-7. Jakarta: Erlangga.

Salura, P. (2010). Arsitektur yang Membodohkan. Bandung: CSS Publishing.

Vitruvius. (1914). The Ten Books on Architecture. London: Oxford University Press.

Zevi, Bruno. (1978). The Language of Modern Architecture. Amerika Serikat: University of Washington Press.

Sandi Siregar, P. (1995). Sikap dan Pemikiran : Suhartono Susilo. Bandung.

Jenks, Charles. Kropf,Karl.(1997).Theories and manifestoes of contemporary architecture. England:Wiley.

Sopandi, Setiadi.(2013).Sejarah Arsitektur: Sebuah pengantar.Jakarta: PT Gramedia Pustaka Utama. Colquhoun, Alan.(2002).Modern Architecture. New York: Oxford University Press.

\section{Sumber Internet}

The Vitruvian Virtues of Architecture: Utilitas, Firmitas, Venustas. (n.d). Diakses tanggal 5 Desember 2016, dari http://art3idea.psu.edu/locus/vitruvius2.pdf

Diagraming Aesthetices (n.d) Diakses tanggal 12 September 2016, dari http://www.slideshare.net/janicemaireneechiverri/03architecturalprincipleselements?next_slid eshow $=1$ 